\title{
Detection of Antibiotic Resistant Genes in Salmonella Isolated From Poultry
}

\author{
Hamza M. I. Eid , Soad A. Nasef, Nosaiba M.Hassonna* \\ Dept. of Bacteriology, Mycology and Immunology, Fac. of Vet. Medicine, \\ Suez Canal Univ., Egypt \\ *Animal Health Research Institue, Dokki, Egypt
}

\begin{abstract}
:
Three hundred samples of infected and freshly dead chickens from different farms gathered in Hehia city El-sharkia for bacteriological examination to detect the presence of Salmonella, 23 Salmonella isolates were detected from 300 samples.Serological results detected Salmonella enteritidis with percentage $26.1 \%$, followed by Salmonella typhimurium with percentage $17.4 \%$ and Salmonella kentucky $8.7 \%$. All Salmonella isolates were tested for their susceptibility to the following antimicrobial agents: gentamicin $(\mathrm{CN})$, ,ciprofloxacin (CIP), amoxicillin- clavulanic acid $(\mathrm{AMC})$, , doxycyclin (DO), chloramphenicol (C), erythromycin (E), sulfamethoxazole -trimethoprim (SXT) High rate of susceptibility was the most common finding obtained against ciprofloxacin (75\%) as shown in table (24). Also, absolute resistance was obtained among Salmonella isolates against erythromycin (100\%) and amoxicillin clavulanic acid $(100 \%)$, and sulfamethoxazole trimethoprim (25\%).In addition, $33.3 \%$ of isolates were resistant to chloramphenicol, and colistin sulfate. All isolates were resistant to at least three antibiotics and multidrug resistance was seen .PCR detected 6 types of antibiotic resistant genes ( $a a d B$ gene, $q n r S$ gene ,sull gene, floR gene ,dfrA gene and blaTEM gene) in percentage $91.7 \%, 83.3 \%, 66.7 \%, 75 \%, 33.3 \%$ and $83.3 \%$ respectively .
\end{abstract}

Key words: Salmonella, antibiotic resistance, genes, poultry.

\section{Introduction}

Salmonella infections were the second most frequently detected zoonoses in humans in Europe. However, there has been a remarkable decrease in the number of detected cases in the last five years (European Food Safety
Authority and European Centre for Disease Prevention and Control, 2011).

Antimicrobial resistance, in particular multidrug resistance (MDR), is a serious and growing phenomenon and has emerged as one of the pre-eminent public health 
concerns of the 21 st century as it pertains to foodborne pathogens. Surveys conducted by the National Antimicrobial Resistance Monitoring System (NARMS) indicate that retail meat is frequently contaminated with multidrug-resistant Escherichia coli, Salmonella and S. aureus (Food and Drug Administration, 2007).

Analysis of the genetic structure of bacterial pathogens detects that virulence genes often found in localized regions of the chromosome, called Salmonella pathogenicity islands (Groisman and Ochman, 1996). There are more than 2,500 different serotypes of Salmonella worldwide. Most species are associated with disease in a wide range of vertebrates. Few serotypes are host specific and majority of them have ubiquitous habits (Sharma and Adlakha 1996 and Quinn et al, 2002). Antimicrobial-resistant strains of Salmonella sp. suffuse all over the world as aresult of the spread of multi-drug-resistant strains. In developed countries, most of resistant strains are of zoonotic origin and have gain over their resistance in an animal host before being transfered to humans througe the food chain (Molbak et al, 2002; Threlfall, 2002 and WHO, 2004).

The objective of this study is:

1. Isolation and biotyping of Salmonella species from different samples of chicken.
2. Serotyping of Salmonella isolates by different monovalent and polyvalent sera.

3. Characterization of antimicrobial resistance patterns for the isolates by disc diffusion method.

4. Incidence of different antibiotic resistance genes by PCR detection.

\section{Materials and Methods \\ 2.1.sampling}

A total of 300 samples (liver, heart and spleen; 100 from each organ) were collected from diseased and freshly dead broiler chickens. Clinical tissue samples (liver, heart and spleen) were collected aseptically to prevent cross contamination using sterile sampling materials (swabs, bags and syringes) and wearing disposable gloves. The samples were collected and transported in ice boxes with ice packs as early as possible to the laboratory for bacteriological examination.

\subsection{Isolation of Salmonella and serotyping}

The procedure for isolation and identification of Salmonellae were conducted according to ISO 6579 (2002) procedure. Suspected Salmonella colonies were confirmed serologically by Kauffman - White scheme (Kauffman, 1974) for the determination of Somatic $(\mathrm{O})$ and flagellar (H) antigens using Salmonella antiserum (DENKA SEIKEN Co., Japan). and biochemically by (TSI), Urea hydrolysis test, Lysine decarboxylation test, Indole 
production test and Citrate utilization test. The isolates were then serotyped by the Animal health research institute in Dokki -Giza . Only confirmed Salmonella were tested for their susceptibility to antimicrobial agents and the presence of the antimicrobial resistant genes.

\subsection{Resistance to the antimicrobial agents}

The antibiotic susceptibility was determined according to the recommendations set by the Clinical and Laboratory Standards Institute (Clinical and Laboratory Standards Institute, CLSI, 2007) for the disk diffusion technique. The antimicrobials and concentrations tested were ampicillin $(10 \mu \mathrm{g})$, gentamicin $(10 \mu \mathrm{g})$, tetracycline $(30 \mu \mathrm{g})$ and sulfamethoxazole (25 $\mu \mathrm{g}$ ) (Oxoid, United Kingdom).The inhibition zones were measured and scored as sensitive, inter- mediate susceptibility or resistant according to the CLSI recommendations.

\subsection{Identification of the resistance genes}

Polymerase chain reaction for amplification of the most important antibiotic resistant genes of Salmonella isolates Extraction of DNA according to QIAamp DNA mini kit instructions. Preparation of PCR Master Mix according to Emerald Amp GT PCR mastermix (Takara) Code No. RR310A kit. DNA Molecular weight marker. The ladder was mixed gently by pipetting up and down. $6 \mu \mathrm{l}$ of the required ladder were directly loaded
.Agarose gel electrophoreses (Sambrook et al., 1989) with modification.Electrophoresis grade agarose $(2 \mathrm{~g})$ was prepared in 100 $\mathrm{ml}$ TBE buffer in a sterile flask, it was heated in microwave to dissolve all granules with agitation, and allowed to cool at $70^{\circ} \mathrm{C}$, then $0.5 \mu \mathrm{g} / \mathrm{ml}$ ethedium bromide was added and mixed thoroughly.

The warm agarose was infused in gel casting apparatus with comb in apposition and left at room temperature for polymerization then remove the comb. The electrophoresis tank was filled with TBE buffer, $20 \mu \mathrm{l}$ of each PCR product samples, negative control and positive control were loaded to the gel. The power supply was 1-5 volts $/ \mathrm{cm}$ of the tank length. The run was stopped after about $30 \mathrm{~min}$ and the gel was transferred to UV cabinet. The gel was photographed by a gel documentation system and the data was analyzed through computer software.

\section{Results}

3.1.Prevalence of Salmonella species in different organs of chickens in El-Sharkia Governorate. Twenty three Salmonella isolates were recovered from 300 examined samples collected from chickens $(7.7 \%)$.

These isolates were isolated from different organs with a higher recovery rate from liver( $12 \%$ )followed by spleen $(8 \%)$ and heart( $3 \%)$. 
3.2. Isolation and identification of Salmonella isolates:

3.2.1.. Colonial appearance:

Salmonella grown onto MacConkey's agar medium gave pale colonies (non lactose fermenter),subculturing from MaCconkey's agar onto xylose lysine desoxy cholate agar medium yielding colonies with aslightly transparent zone of reddish colour with or without black center. While that grown onto Salmonella-shigella agar gave pale colonies with or without black centers.

3.2.2. Microscopical examination:

Salmonella isolates were Gram negative, medium sized bacilli, arranged singly, in pairs and in groups and they were non spore forming.

3.2.3. Biochemical identification:

All Salmonella isolates were urea negative (yellow colour),citrate positive (blue colour),Salmonella isolates gave acid butt(yellow)and alkaline slant(red)with H2S production (black coloration) on TSI agar medium.

3.2.4. Serotyping of some Salmonellae isolates from chickens: Serotyping of 12 Salmonella isolates was applied by slide agglutination test using specific polyvalent "O" I, II, III and "H" Salmonella sera. Three different serotypes were identified among selected Salmonella isolates ; The different serogroups were identified and Salmonella enteritidis was the most prevalent one with percentage of $(26.1 \%)$. Other serotypes as Salmonella typhimurium, Salmonella kentucky and untyped strains .Were also recorded with percentage of $(17.4 \%, 8.7 \%, 47.8 \%)$ respectively.

4.3. Results of antimicrobial susceptibility testing:

All Salmonella isolates were tested for their susceptibility to the following antimicrobial agents: gentamicin $(\mathrm{CN}), \quad$,ciprofloxacin (CIP), amoxicillin- clavulanic acid (AMC), , doxycyclin (DO), chloramphenicol (C), erythromycin (E), sulfamethoxazole trimethoprim (SXT) High rate of susceptibility was the most common finding obtained against ciprofloxacin $(75 \%)$ and as shown in table (24). Also, absolute resistance was obtained among Salmonella isolates against erythromycin (100\%) and amoxicillin clavulanic acid (100\%), and sulfamethoxazole trimethoprim (25\%).In addition, $33.3 \%$ of isolates were resistant to chloramphenicol, and colistin sulfate. All isolates were resistant to at least three antibiotics and multidrug resistance was seen . 
Table(1): Different serotypes of selected Salmonella and their percentage

\begin{tabular}{|l|l|c|c|c|c|c|}
\hline Organ & \multicolumn{2}{|c|}{$\begin{array}{l}\text { positive } \\
\text { Salmonella }\end{array}$} & \multicolumn{5}{|c|}{ Serotypes( 23) } \\
\cline { 3 - 7 } & \multicolumn{2}{l}{\begin{tabular}{l} 
Isolates \\
\cline { 2 - 7 }
\end{tabular}} & S. enteritidis & S.typhimurium & S.kentucky & Untyped \\
\hline $\begin{array}{l}\text { Liver } \\
(100)\end{array}$ & 12 & $12 \%$ & 4 & 3 & 1 & 4 \\
\hline $\begin{array}{l}\text { Spleen } \\
(100)\end{array}$ & 8 & $8 \%$ & - & 1 & 1 & 6 \\
\hline $\begin{array}{l}\text { Heart } \\
(1 \mathrm{~s} 00)\end{array}$ & 3 & $3 \%$ & 2 & - & - & 1 \\
\hline $\begin{array}{l}\text { Total } \\
(300)\end{array}$ & 23 & $7.7 \%$ & $6(26.1 \%)$ & $4(17.4 \%)$ & $2(8.7 \%)$ & $11(47.8 \%)$ \\
\hline
\end{tabular}

Table (2): Antibiogram of the obtained Salmonella isolates

\begin{tabular}{|c|c|c|c|c|c|c|c|c|c|c|c|c|}
\hline \multirow[b]{2}{*}{$\begin{array}{c}\text { Code no. } \\
\text { of samples }\end{array}$} & & & \multicolumn{10}{|c|}{ Antibacterials } \\
\hline & $\sum$ & Z & 它 & U & 武 & ? & U & $\mathbb{\approx}$ & $\hat{\jmath}$ & 常 & $\overleftrightarrow{z}$ & 되 \\
\hline 13 & $\mathbf{R}$ & I & $\mathbf{R}$ & $\mathbf{R}$ & $\mathbf{R}$ & $\mathbf{R}$ & $\mathbf{S}$ & $\mathbf{R}$ & $\mathbf{S}$ & $\mathbf{S}$ & $\mathbf{R}$ & $\mathbf{R}$ \\
\hline 14 & $\mathbf{R}$ & $\mathbf{S}$ & I & $\mathbf{R}$ & I & $\mathbf{S}$ & I & $\mathbf{R}$ & $\mathbf{S}$ & $\mathbf{S}$ & I & $\mathbf{R}$ \\
\hline 15 & $\mathbf{R}$ & I & $\mathbf{S}$ & $\mathbf{R}$ & $\mathbf{R}$ & $\mathbf{S}$ & I & $\mathbf{R}$ & $\mathbf{R}$ & $\mathbf{I}$ & $\mathbf{R}$ & $\mathbf{R}$ \\
\hline 2 & $\mathbf{R}$ & I & $\mathbf{S}$ & $\mathbf{R}$ & $\mathbf{S}$ & $\mathbf{S}$ & $\mathbf{R}$ & $\mathbf{R}$ & $\mathbf{S}$ & $\mathbf{S}$ & I & $\mathbf{R}$ \\
\hline 6 & $\mathrm{R}$ & I & $\mathrm{S}$ & $\mathrm{R}$ & I & $\mathrm{S}$ & $\mathrm{S}$ & $\mathrm{R}$ & $\mathrm{S}$ & $\mathrm{S}$ & $\mathrm{R}$ & $\mathrm{R}$ \\
\hline 7 & $\mathrm{R}$ & $\mathrm{S}$ & $\mathrm{S}$ & $\mathrm{R}$ & $\mathrm{S}$ & $\mathrm{S}$ & $\mathrm{S}$ & $\mathrm{R}$ & $\mathrm{S}$ & $\mathrm{S}$ & $\mathrm{R}$ & $\mathrm{R}$ \\
\hline 31 & $\mathrm{R}$ & $\mathrm{S}$ & $\mathrm{R}$ & $\mathrm{R}$ & $\mathrm{R}$ & I & $\mathrm{R}$ & $\mathrm{R}$ & $\mathrm{S}$ & $\mathrm{S}$ & $\mathrm{R}$ & $\mathrm{R}$ \\
\hline 32 & $\mathrm{R}$ & I & $\mathrm{R}$ & $\mathrm{R}$ & $\mathrm{R}$ & $\mathrm{R}$ & $\mathrm{R}$ & $\mathrm{R}$ & I & $\mathrm{S}$ & $\mathrm{R}$ & $\mathrm{R}$ \\
\hline 90 & $\mathrm{R}$ & I & $\mathrm{R}$ & $\mathrm{R}$ & $S$ & I & $\mathrm{R}$ & $\mathrm{R}$ & $\mathrm{S}$ & $\mathrm{S}$ & $\mathrm{R}$ & $\mathrm{R}$ \\
\hline 99 & $\mathrm{R}$ & I & I & $\mathrm{R}$ & $\mathrm{R}$ & $\mathrm{R}$ & $\mathrm{S}$ & $\mathrm{R}$ & $\mathrm{S}$ & $\mathrm{S}$ & $\mathrm{R}$ & $\mathrm{R}$ \\
\hline 110 & $\mathrm{R}$ & I & I & $\mathrm{R}$ & $\mathrm{R}$ & $\mathrm{R}$ & $\mathrm{R}$ & $\mathrm{R}$ & I & $\mathrm{R}$ & $\mathrm{R}$ & $\mathrm{R}$ \\
\hline 78 & $\mathrm{R}$ & $\mathrm{R}$ & I & $\mathrm{R}$ & $\mathrm{R}$ & $\mathrm{R}$ & I & $\mathrm{R}$ & $\mathrm{S}$ & $\mathrm{R}$ & $\mathrm{R}$ & $\mathrm{R}$ \\
\hline
\end{tabular}

Prevalence of different genes detected by PCR among 12 Salmonella isolates: 


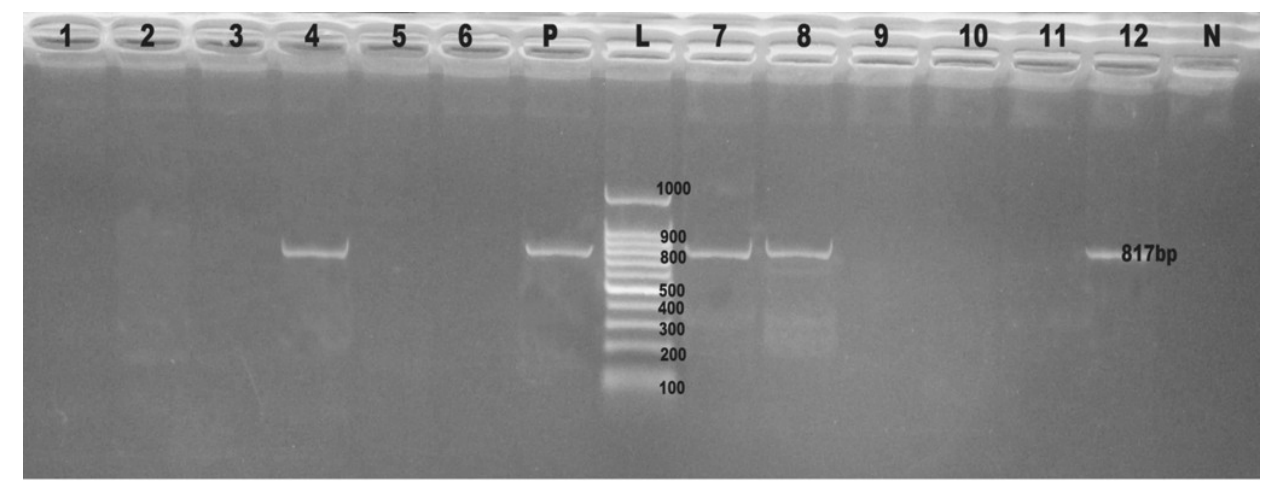

Fig. (1): Agarose gel electrophoresis showing the result of PCR for detection of dfrA gene from 12 Salmonella isolates.

Lanes 1,2,3,4,4,6,7,8,9,10,11,12:Salmonella species

Lane P: positive $d f r A$ control(refrence strain)

Lanes 4,7,8,12: positive amplification of $817 \mathrm{bp}$ for $d \mathrm{fr} A$ gene of different

Salmonella species. Salmonella isolates of code No.(2-6-14-90)

Lane L: the DNA molecular weight marker (Gelpilot 100bp ladder).

Lane N: negative $d f r A$ control.(control negative).

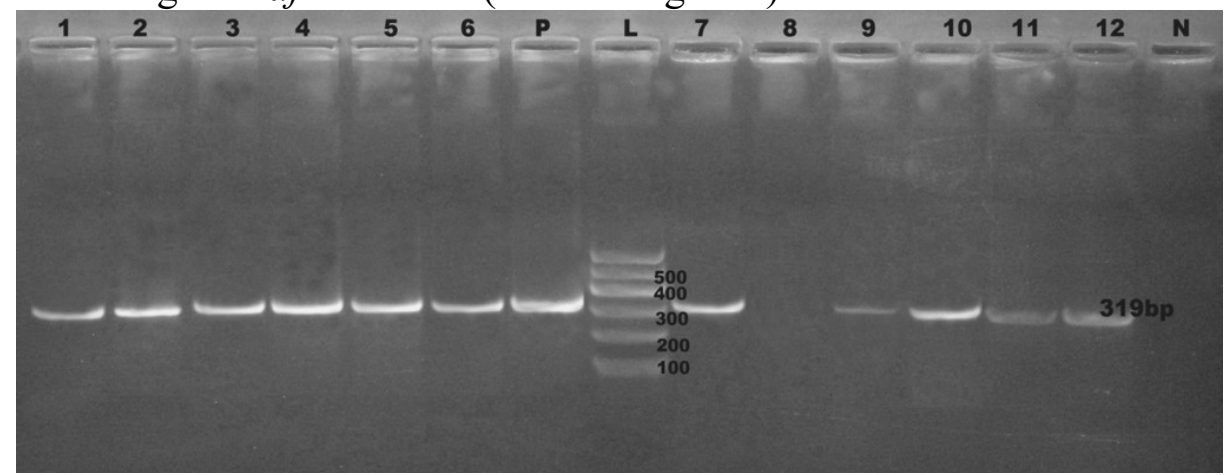

Fig. (2): Agarose gel electrophoresis showing the result of $P C R$ for detection of aadB gene from 12 Salmonella isolates

Lanes 1,2,3,4,4,6,7,8,9,10,11,12: Salmonella species.

Lane P: positive $a a d B$ control. (refrence strain)

Lanes 1,2,3,4,5,6,7,9,10,11,12: positive amplification of 319bp for aadB gene of different Salmonella species.

Lane 8: negative amplification of 319bp for $a a d B$ gene of different

Salmonella species.

Lane L: the DNA molecular weight marker (Gelpilot 100bp ladder).

Lane N: negative $a a d B$ control.( control negative) 


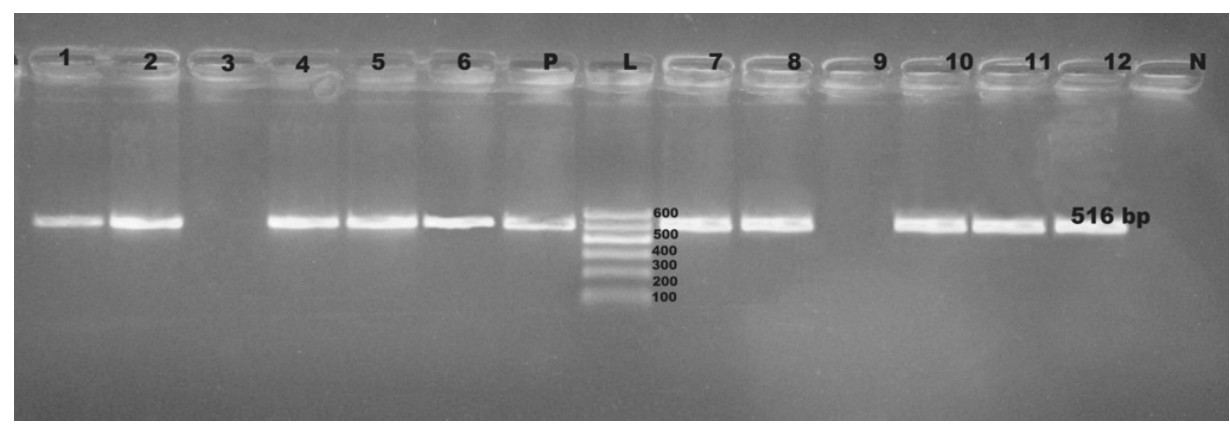

Fig. (3): Agarose gel electrophoresis showing the result of PCR for detection of bla ${ }_{T E M}$ gene from 12 Salmonella isolates.

Lanes 1,2,3,4,4,6,7,8,9,10,11,12:Salmonella species

Lane P: positive $b l a_{T E M}$ control (refrence strain).

Lanes 1,2,4,5,6,7,8,10,11,12: positive amplification of 516bp for bla $a_{T E M}$ gene of different Salmonella species.

Lanes 3,9: negative amplification of 516bp for bla $_{T E M}$ gene of different Salmonella species.

Lane L: the DNA molecular weight marker (Gelpilot 100bp ladder).

Lane N: negative $b l a_{T E M}$ control.( control negative).

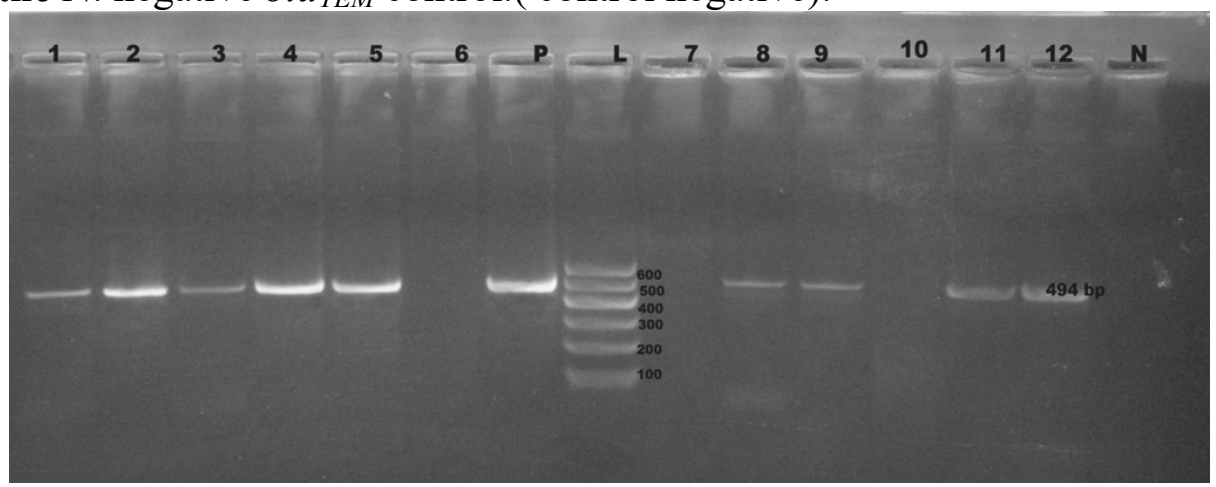

Fig. (4): Agarose gel electrophoresis showing the result of $P C R$ for detection of floR gene from 12 Salmonella isolates.

Lanes 1,2,3,4,4,6,7,8,9,10,11,12:Salmonella species

Lane P: positive floR control(refrence strain).

Lanes 1,2,3,4,5,8,9,11,12: positive amplification of 494bp for floR gene of different Salmonella species.

Lanes 6,7,10: negative amplification of 494bp for floR gene of different Salmonella species

Lane L: the DNA molecular weight marker (Gelpilot 100bp ladder).

Lane N: negative floR control.( control negative). 


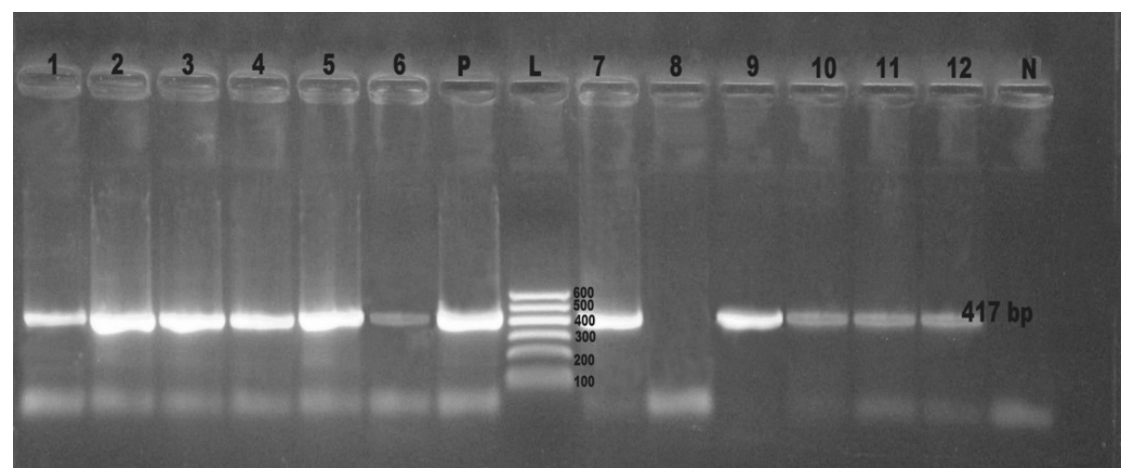

Fig. (5): Agarose gel electrophoresis showing the result of PCR for detection of qnrS gene from 12 Salmonella isolates.

Lanes 1,2,3,4,4,6,7,8,9,10,11,12:Salmonella species

Lane P: positive $q n r S$ control(refrence strain).

Lanes 1,2,34,5,6,7,9,10,11,12: positive amplification of 417bp for $q n r S$ gene of different Salmonella species.

Lane 8: negative amplification of $417 \mathrm{bp}$ for $q n r S$ gene of different Salmonella species

Lane L: the DNA molecular weight marker (Gelpilot 100bp ladder). Lane N: negative $q n r S$ control.( control negative).

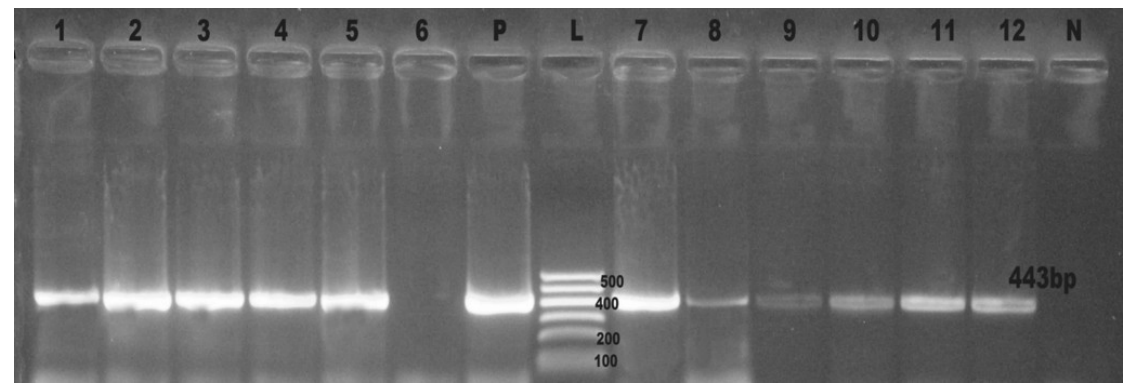

Fig. (6): Agarose gel electrophoresis showing the result of PCR for detection of Sull gene from 12 Salmonella isolates.

Lanes 1,2,3,4,4,6,7,8,9,10,11,12:Salmonella species

Lane P: positive Sull control(refrence strain).

Lanes 1,2,3,4,5,7,8,9,10,11,12: positive amplification of 417bp for $q n r S$ gene of different Salmonella species.

Lane 6: negative amplification of 443bp for Sull gene of different Salmonella species.

Lane L: the DNA molecular weight marker (Gelpilot 100bp ladder).

Lane N: negative Sull control.( control negative).

phenotypic and genotypic methods of different Salmonella species. 
Table(3) Antibiotic resistance and Antibiotic resistance gene in Salmonella Serovars isolated from chicken

\begin{tabular}{|c|c|c|c|c|c|c|c|c|c|c|c|c|}
\hline \multirow[t]{2}{*}{ Serovar } & \multirow{2}{*}{$\begin{array}{c}\text { NO. } \\
\text { of } \\
\text { isola } \\
\text { te }\end{array}$} & \multicolumn{2}{|c|}{ AMC } & \multicolumn{3}{|c|}{ SXT } & \multicolumn{2}{|c|}{$\mathbf{C N}$} & \multicolumn{2}{|c|}{ C } & \multicolumn{2}{|c|}{ N.A } \\
\hline & & $\mathbf{A M}$ & $\begin{array}{c}b^{b l a} a_{T} \\
E M\end{array}$ & SXT & Sul1 & $d f r A$ & $\mathbf{C N}$ & $\begin{array}{c}\text { aad } \\
B\end{array}$ & C & $\begin{array}{c}\text { flo } \\
R\end{array}$ & $\begin{array}{l}\mathbf{N} . \\
\text { A }\end{array}$ & $\begin{array}{c}q n r \\
S\end{array}$ \\
\hline S.enteritis & 6 & 6 & 5 & 3 & 3 & 2 & - & 6 & 3 & 3 & 5 & 5 \\
\hline $\begin{array}{l}\text { S.typhimu } \\
\text { rium }\end{array}$ & 4 & 4 & 3 & 3 & 3 & 1 & 1 & 4 & 2 & $\varepsilon$ & 4 & 4 \\
\hline $\begin{array}{l}\text { S.kentuck } \\
y\end{array}$ & 2 & 2 & 2 & 1 & 2 & 1 & - & 1 & - & 2 & 1 & 1 \\
\hline Total (\%) & 12 & $\begin{array}{c}12 \\
100 \\
\%\end{array}$ & $\begin{array}{c}10 \\
83.3 \\
\%\end{array}$ & $\begin{array}{c}7 \\
58.3 \\
\%\end{array}$ & $\begin{array}{c}8 \\
66.7 \\
\%\end{array}$ & $\begin{array}{c}4 \\
33.3 \\
\%\end{array}$ & $\begin{array}{c}1 \\
8.3 \\
\%\end{array}$ & $\begin{array}{c}11 \\
91.7 \\
\%\end{array}$ & $\begin{array}{c}5 \\
41.7 \\
\%\end{array}$ & $\begin{array}{c}9 \\
75 \\
\%\end{array}$ & $\begin{array}{l}10 \\
83 . \\
\%\end{array}$ & $\begin{array}{c}10 \\
83.3 \\
\%\end{array}$ \\
\hline
\end{tabular}

Table (4) Association between phenotypic antimicrobial result and distribution of antibiotic resistance gene among diff. Salmonella serotypes.

\begin{tabular}{|c|c|c|c|c|c|c|c|c|c|}
\hline Salmonella species & $\begin{array}{l}\text { Code } \\
\text { NO. }\end{array}$ & $\mathrm{AMC}$ & STX & $\mathrm{CN}$ & $\mathrm{C}$ & CIP & NOR & NA & $\begin{array}{l}\text { Distribution of antibiotic } \\
\text { resistance gene }\end{array}$ \\
\hline S.kentucky & 13 & $\mathrm{R}$ & $\mathrm{R}$ & I & $\mathrm{S}$ & $\mathrm{S}$ & $\mathrm{S}$ & $\mathrm{R}$ & $\begin{array}{c}\text { Sull-aadB-floR-qnrS- } \\
\text { blaTEM }\end{array}$ \\
\hline S.kentucky & 14 & $\mathrm{R}$ & 1 & S & 1 & $\mathrm{~S}$ & $\mathrm{~S}$ & $T$ & Sull-flor-blaTEM -dfrA \\
\hline S.enteritidis & 15 & $\mathrm{R}$ & $\mathrm{R}$ & $\mathrm{I}$ & $\mathrm{I}$ & $\mathrm{I}$ & $\mathrm{I}$ & $\mathrm{R}$ & Sull-aadB-floR-qnrS \\
\hline S.enteritidis & 2 & $\mathrm{R}$ & $\mathrm{S}$ & I & $\mathrm{R}$ & $\mathrm{S}$ & $\mathrm{S}$ & I & $\begin{array}{l}\text { Sull-aadB-floR-qnrS- } \\
\text { blaTEM -dfrA }\end{array}$ \\
\hline S.enteritidis & 6 & $\mathrm{R}$ & I & I & $\mathrm{S}$ & $\mathrm{S}$ & $\mathrm{S}$ & $\mathrm{R}$ & $\begin{array}{c}\text { Sull-aadB-qnrs- blaTEM - } \\
\text { dfrA }\end{array}$ \\
\hline S.enteritidis & 7 & $\overline{\mathrm{R}}$ & $\mathrm{S}$ & 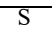 & $\mathrm{S}$ & $\mathrm{S}$ & $\mathrm{S}$ & $\mathrm{R}$ & aadB-qnrS-blaTEM \\
\hline S.enteritidis & 31 & $\mathrm{R}$ & $\mathrm{R}$ & S & $\mathrm{R}$ & $\mathrm{S}$ & $\mathrm{S}$ & $\mathrm{R}$ & Sul1-aadB-qnrS-blaTEM \\
\hline S.enteritidis & 32 & $\mathrm{R}$ & $\mathrm{R}$ & I & $\mathrm{R}$ & I & $\mathrm{S}$ & $\mathrm{R}$ & $\begin{array}{c}\text { Sull-aadB-floR-qnrS- } \\
\text { blaTEM }\end{array}$ \\
\hline S.typhimurium & 90 & $\mathrm{R}$ & $\mathrm{S}$ & I & $\mathrm{R}$ & $\mathrm{S}$ & $\mathrm{S}$ & $\mathrm{R}$ & $\begin{array}{l}\text { Sull-aadB-floR-qnrS- } \\
\text { blaTEM -dfr }\end{array}$ \\
\hline S.typhimurium & 99 & $\mathrm{R}$ & $\mathrm{R}$ & 1 & $\mathrm{~S}$ & $\mathrm{~S}$ & $\mathrm{~S}$ & $\mathrm{R}$ & Sull-aadB-floR-qnrS \\
\hline S.typhimurium & 110 & $\mathrm{R}$ & $\mathrm{R}$ & I & $\mathrm{R}$ & I & $\mathrm{R}$ & $\mathrm{R}$ & $\begin{array}{c}\text { Sull-aadB-floR-qnrS- } \\
\text { blaTEM }\end{array}$ \\
\hline S.typhimurium & 78 & $\mathrm{R}$ & $\mathrm{R}$ & $\mathrm{R}$ & I & $\mathrm{S}$ & $\mathrm{R}$ & $\mathrm{R}$ & $\begin{array}{c}\text { Sul1-aadB-floR-qnrS- } \\
\text { blaTEM }\end{array}$ \\
\hline
\end{tabular}




\section{Discussion}

In the present study examination of 300 samples collected from diseased chickens' samples from Sharkia ,23 Salmonella isolates was isolated in an overall prevalence of $7.7 \%(23 / 300), \quad 12 \%$ was from liver, while, $8 \%$ from spleen and $3 \%$ from heart.XLD agar uses the ability of Salmonellae to ferment xylose, decarboxylate lysine and reproduce hydrogen sulfide in addtion to the selective activity of the bile salt (detergent).On XLD agar,coliforms and protus sp. are diffrentiated by lactose and sucrose fermentation respectively (Galton et al, 1988). Salmonella was previously isolated from chicken by (Al-Shawabkeh and Yamani, 1996; Mohammed et al, 1999; Taha, 2002; Ahmed, 2003; Orji et al., 2005; Pieskus et al., 2006; Moawad, 2009; Maripandi and Ali, 2010 and Shah and Korejo, 2012) .In the present work, antimicrobial susceptibility test was done by disk diffusion method to explore antibiogram result as appear in table(1) to correlate phynotypic resistance with genotypic one as listed in table (3) Ciprofloxacin and Norfloxacin are potent broad-spectrum antimicrobial agents that are increasingly used to treat Salmonellosis infection. Despite initial optimism, resistance to these antibiotics has increased significantly since their introduction into medicine in the late 1980's and early 1990's. Mutational alterations in the fluoroquinolone target enzymes are recognized to be the major mechanisms through which resistance develops. In present study susceptibility of Salmonella isolates to Ciprofloxacin and Norfloxacin is $75 \%$.These results go hand in hand with Miko et al (2005) who detected a small number of isolates that were resistant to gentamycin And high percentage of resistance to amoxicillin and Sulfamethoxazoletrimethoprime..On the other hand these results differ from those obtained by Fazlina et al (2012) who found that susceptibility of their Salmonella isolates to gentamicin, ciprofloxacin and chloramphenicol was $95 \%, 90 \%$ and $80 \%$, respectively and high level of resistance was observed against amoxicillin clavulanic acid $(100 \%)$ and erythromycin (80\%). And yang et ai., who found that resistance of their Salmonella isolates to Sulfamethoxazoletrimethoprime ,nalidixic acid , Amoxycillin, chloramphincol and Gentamycin was 58\%,35\%,32\%,26\% and $26 \%$ respectively. In the present investigation, it was noted an incidence of multidrug resistance among all 12 Salmonella isolates which was higher than that obtained previously by Shen et al., $2008(28.5 \%)$ and Ahmed et al., 2009a(14.4\%). Schwarz and Chaslus-Dancla, (2001) and Zouhairi et al., (2010) who attributed the exacerbation of this MDR to the diminishing of new 
antibiotics and considered as a serious danger to public health.

Several authors have observed multiple drug resistance in isolates from poultry carcasses and meat (Yang et al, 2001; Capita et al, 2003; Romani et al, 2008; Hur et al, 2011; Yildirim et al, 2011).

resistance genes have become a hot research topic in order to control the spread of multidrug-resistant bacteria. The high levels of resistant isolates reported in many publications may be due to the worldwide overuse of antimicrobials in different fields, which has placed enormous pressure on the selection of antimicrobial re- sistance among bacterial pathogens and endogenous microflora (Capita et al, 2007).

Data in Table (3) \& (4) illustrated the association between phenotypic antimicrobial results and distribution of antibiotic resistance genes among different Salmonella serotypes and reveal the correlation between the antimicrobial resistance pattern and presence of coresponfding antibiotic resistance genes.

In present work , PCR approaches have been applied to detect different antibiotic resistance genes that are ( Sul1, qnrS, floR, bla TEM, aadB and $d f r A$ ).

The data recorded in Table (3) and photographs (6) revealed that Sull gene is detected in 11 strains. Sull gene absent in S.entiritidis with code number 7 that shows sensitivity to Sulfamethoxazole- trimethoprime which indicate relationship between Phenotypic and genotypic features of antibiotic resistance in Salmonella .

These results go hand on hand with Beutlich et al, 2010 who detected Sull gene from Salmonella isolates that show resistance to Sulfamethoxazole.

The gene sequence of aadB as shown in Fig.(2) and Table(3 ) which is detected in only $91.7 \%$ is not correlated with the resistance phenotype to gentamycin $(83 \%)$ in the isolates. There fore using only the biomolecular technique for the study of Antibiotic resistance is restrictive .It must also be noted that acombination of methods is required to determine that the relationships among the isolates as suggested by Capita et al (2007).

The gene sequence of floR and $d f r A$ genes as shown in Fig. $(1,4)$ and Table(3) which were detected in $75 \%$ and $33.3 \%$ respectively arenot correlated with the resistance phenotype to chloramphinicol and SXT $(41.7 \%) \quad$ and $(58.3 \%)$ respectively.This lack of correlation between the resistance phenotype to chloramphenicol and sulfonamide and presence of gene (floR, $d f r A)$ indicates the involvment of anon specific resistance mechanisms. The lack of correlation between antibiotic resistance and the expression of related genes has been also high lighted in astudy conducted in Germany (Miko et al,2005). 
The phenotype of the isolates influenced by both specific and non specific resistance mechanism such as lower membrane permiability and a high active efflux (Brindani et al, 2006; Putman et al, 2000 and Quintiliani et al, 1999).

In these isolates from the investigated samples $b l a_{T E M}$ and $q n r S$ genes were generally expressed phenotypically high lightining the involvement of specific resistance mechanism,as in Table( 4 ), bla $a_{T E M}$ and $q n r S$ which were detected in (83.3\%) are correlated with the resistance phenotype to Amoxicillin and nalidixic acid (100\%)and(83.3\%)respectively .These result agree with Yang et al, 2010 who identified a correlation between the presence of resistant gene bla $a_{T E M}$ and its phenotype. Negative isolate with code 15 show resistance to AMC phenotypically but not expressed gnotypically as it posses other molecular mechanism (e.g., loss of porins genes that were not detected in the present study or multi drug resistance pumps) that are responsible for resistane to $\mathrm{B}$ lactams which couldnot be dtermined in the present work.In order to examine this possibility, this isolate should be investigated futher.

This study focused its alternation on two relevant aspect of phenomenon of antibiotic resistance in Salmonella isolates, The first aspect is concerned with initial optimism resistance to Ciprofloxacin that increased significally scince its introduction into veterinary medicine.

The second aspect focuses on the correlation between aresistance phenotype and the presence of the related genes which is parially displayed .

This also confirm the importance of the invovment of non specific resistance mechanism and therefore the need of simultaneous application of different qualitative techniaue to identify antimicrobial resistance mechanism .Therefore ,although it isnot alawys correlated with the resistance phenotype ,The presence of gene sequence clearly indicates that Salmonella represent a source of the genetic determenants of resistance that is most likely transmissible to closely related bacteria and potentially to other micro organism .

\section{References}

Ahmed H. A.(2003): Tracing some sources of infection of some zoontic bacteria among family Enterobacteriaceae. M.V.Sc.Thesis, Fac. Vet. Med. Zoonoses Department, Zagazig Univerisity. Al - Shawabkeh K and Yamani, M I. (1996): Prevalence of Salmonella in poultry farms in Jordan. Pure Appl. Sci., B, 23 (1): $67-72$.

Beutlich J, Rodríguez I, Schroeter A, Käsbohrer A, Helmuth R, Guerra B.(2010): A predominant multidrug-resistant Salmonella 
enterica serovar Saintpaul clonal line in German turkey and related food products. Appl Environ Microbiol., 76(11):3657-67.

Brindani, F., Bacci, C., Paris, A., Salsi, A., Bonardi, S., (2006): Presence of marRab operon in Salmonella spp. strains isolated from pork and poultry meat. Veterinary Research Communications 30, 341-343.

Capita R, Alvarez-Astrorga M, Alonso-Calleja C, Moreno B and del Camino $G \quad F \quad M \quad$ (2003): Occurrence of Salmonella in retail chickens carcasses and their products in Spain. Int. J. Food Microbiol., 81 (2) : 169-173.

Capita, R., Alonso-Calleja, C., Prieto, M., (2007): Prevalence of Salmonella enterica serovars and genovars from chicken carcasses in slaughterhouses in Spain. Journal of Ap- plied Microbiology 103, 13661375.

CLSI (Clinical and Laboratory Standards Institute) (2011):

Performance standards for antimicrobial susceptibility testing; twentyfirst

informational supplement.; 1-172.

European Food Safety Authority, European Centre for Disease Prevention and Control, (2011): The European Union Summary Report on Trends and Sources of Zoonoses, Zoo- notic Agents and Food-borne Outbreaks in 2009. EFSA Journal 9 (3), 2090.

Fazlina F, Al-Sultan II and Jasbir SI (2012): Antibiotic sensitivity of pathogenic bacteria isolated from beef samples obtained from KotaBharu and its surrounding provinces. Journal of Advanced Medical Research, $2: 8$ 11.

Food and Drug Administration. NARMS retail meat annual report,(2007): Available at: http://www.fda.gov/Animal

Veterinary/Safety Health /AntimicrobialResistance/National Antimicrobial Resistance Monitoring

System/ucm164662.htm. Accessed 29 November 2010.

Galton,M.M.;G.K.Morris;and

W.T.Martin.(1968): Salmonellae in foods and feeds.Communicable Disease Center,Atlanta,Ga.

Groisman E A and Ochman $H$ (1996): Pathogenicity islands: Bacterial evolution in quantum leaps. Cell., 87: 791-794.

Hur, J., Kim, J.H., Park, J.H., Lee, Y.J., Lee, J.H., (2011): Molecular and virulence characteristics of multi-drug resistant Salmonella Enteritidis strains isolated from poultry. Veterinary Journal 189 (3), 306-311.

ISO 6579 (2002): Microbiology of food and animal feeding stuffs. Horizontal methods for the detection of Salmonella species.(4th ed.) international Organization for standardization.

Kauffman F. (1973): Serological diagnosis of Salmonella spp. Kaufmann White Scheme, Copenhagen, Denmark.

Maripandi A and Al-Salamah A A (2010): Multiple-antibiotic resistance and plasmid profiles of 
Salmonella enteritidis isolated from retail chickens meats. American Journal of Food Technology., 5 (4): 260-268.

Miko, A., Pries, K., Schroeter, A., Helmuth, R., (2005): Molecular mechanisms of resistance in multidrug-resistant serovars of Salmonella enterica isolated from foods in Germany. Journal of Antimicrobial Chemotherapy 56, 1025-1033.

\section{Moawad}

AAI

(2009):

Bacteriological studies on Salmonella Enteritidis isolated from different sources in Dakhlia Governorate. M. V. Sc. Thesis, Fac. Vet. Med., Zoonoses: Dept., Zag. University.

Mohammed L N, Smaha H A, Draz $A$ A and Haggage $Y \mathbf{N}$ (1999): Salmonella among birds and human beings. Alex. J. Vet. Sic., (1): 147-154.

Molback M, Gerrner-Smidt $P$ and Wegener HC (2002) : Increasing quinolone resistance in Salmonella enterica serotype Enteritidis. Emerg. Infect. Dis., 8 (5): 514-515.

Orji $M$ U, Onuigbo $H C$ and Mbata T I (2005): Isolation of Salmonella from poultry dropping and other environmental sources in Awka, Nigeria. Int. J. Inf. Dis., 9 (2): 86-89.

Pieskus J, Milius J, Michalskiene I and Zagrebneviene $G$ (2006): The distribution of Salmonella serovars in chickens and human in Lithuania. Journal of Veterinary Medicine., 53 (1): 12-16.
Putman, M., Van Veen, H.W., Konings, W.N., (2000): Molecular properties of bacterial multidrug transporters. Microbiology and Molecular Biology Reviews 64 (4), 672-693.

Quinn P J, Carter M E, Markey $B \quad K$ and Carter G R (1994): Clinical Veterinary Microbiology. Salmonella serotypes. S. Livingstone, limited, Edinburgh and New York, 226 -234 .

Quinn P J, Markey B K, Carter $M$ E, Donnelly $W \quad J \quad C$ and Leonard F C (2002): Veterinary Microbiology and Microbial Diseases. Salmonella serotypes. Great Britain by HPG, Books Ltd., Bodmin, Cornwall, UK. P.114- 118.

Quintiliani Jr., R., Sahm, D.F., Courvalin, P., (1999): Mechanisms of resistance to antimi- crobial agents, In: Murray, P.R., Baron, E.J., Pfaller, M.A., Tenover, F.C., Yolken, R.H. (Eds.), Manual of Clinical Microbiology, 7th ed. American Society for Microbiology, Washington, D.C., pp. 1505-1525.

Romani, C., Aleo, A., Pellissier, N., Vigano, A., Pontello, M., (2008): Characterization of multidrug resistance in Salmonella strains isolated from animals. Annali dell'Istituto Superiore di Sanità 44, 292-300.

Sambrook J, Fritsch E F and Maniatis $T$ (1989): Molecular cloning: a laboratory manual, 2nd Edition. Cold Spring Harbor Laboratory Press, New York. 
Shah A H and Korejo N A (2012): Antimicrobial resistance profile of Salmonella serovars isolated from chicken meat. J. Vet. Anim . Sci., (2): 40-46.

Sharma $\mathbf{S} \mathbf{N}$ and Adlakha $\mathbf{S} \mathbf{C}$ (1996): Textbook of Veterinary Microbiology. Enterobacteriaceae., Vikas. Publishing house Chapter 39, 206- 210.

Taha, N A A (2002): Zoonotic importance of enter pathogenic E.coli (EPEC). PhD Thesis, Fac.Vet. Med. Zagazig University.

Threlfall E J (2002): Antimicrobial drug resistance in Salmonella problems and perspectives in foodand water-borne infections. FEMS Microbiol. Rev., 26: 141-148. WHO (2004): 1 st Joint 7.
Usage

and

Antimicrobial

Resistance: Scientific Assessment, Geneva, 1-5.

Yang, S.J., Park, K.Y., Seo, K.S., Besser, T.E., Yoo, H.S., Noh, K.M., Kim, S.H., Kim, S.H., Lee,B.K., Kook, Y.H., Park, Y.H., (2001):Multidrug-resistant

Salmonella Typhimurium and Salmonella Enteritidis identified by multiplex PCR from animals. Journal of Veteri- nary Science 2, 181-188.

Yildirim, Y., Gonulalan, Z., Pamuk, S., Ertas, N., \{2011): Incidence and antibiotic resistance of Salmonella spp. on raw chicken carcasses.Food Research International 44 (3), 725-

FAO/OIE/WHO Expert Workshop on Non-human Antimicrobial

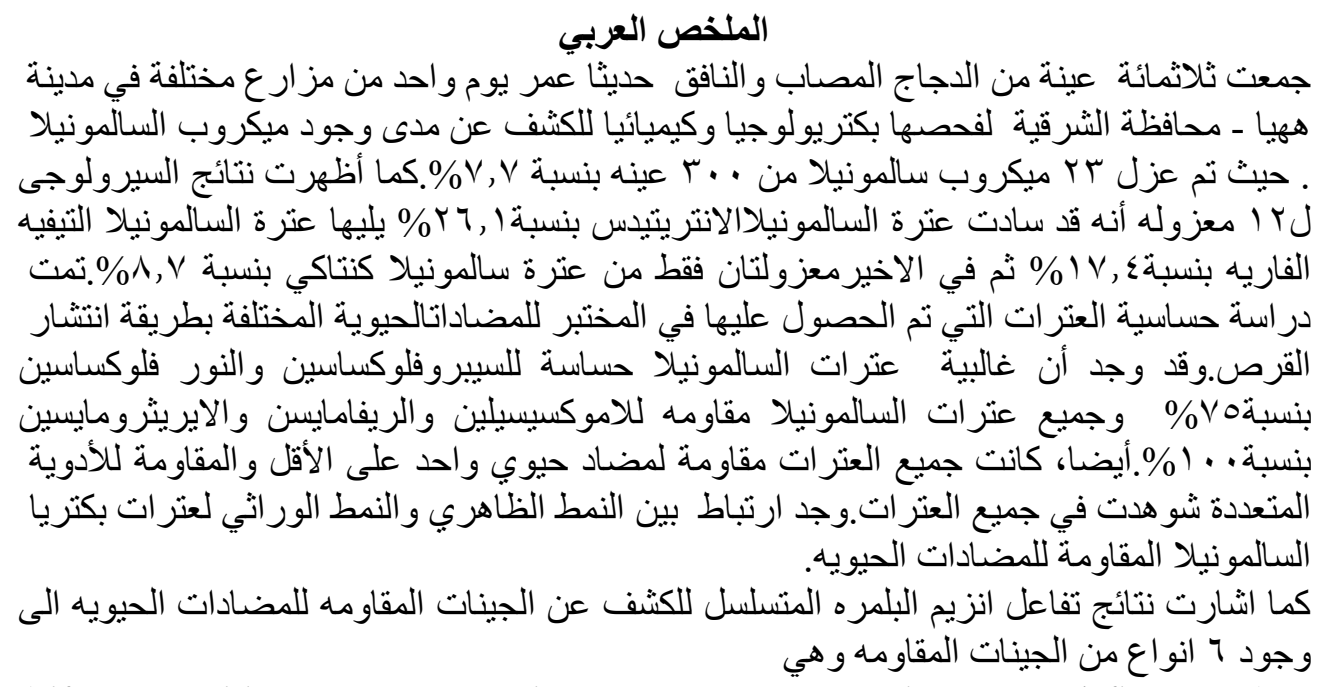
(dfrA gene, blaTEM gene, aadB gene, qnrS gene ,sull gene and floR gene). 